\title{
Limited to Recognition: The Trinidadian State and its Indigenous Population
}

\author{
Adam Rudder \\ University of Toronto \\ FAS Philosophy, Psychology and Caribbean Studies
}

\section{A B S T R A C T}

One prevalent issue regarding the enfranchisement of Indigenous communities within the politics of the Caribbean includes the idea that such communities cease to exist. Though the impact of European colonization in the region proved to be destructive to Indigenous ways of life, this impact was far from exterminatory, and Caribbean governments and authorities who argue the contrary base their testimony upon groundless claims. This paper analyses the actions of Trinidad and Tobago's post-independence government in curating a nationalist discourse based on the histories of its Afro-Creole population, and how that discourse was ultimately founded on a complete disregard for the country's Indigenous population. The paper first delves into the colonial extinction narratives that have served to restrain Trinidad's Indigenous community, then it investigates various biological and historical evidence that prove Indigenous diffusion beyond the limits outlined in extinction narratives. Finally, Trinidad's Afro-Creole-based nationalism is explored to gain insight on how such an ethnically-driven nationalism has hindered the concerns of Trinidad's overall Indigenous community.

\section{Keywords:Afro-Creole, DNA, extinction, Indigenous, miscegenation, post-indepen- dence, Santa Rosa, Trinidad and Tobago}

\section{B I O}

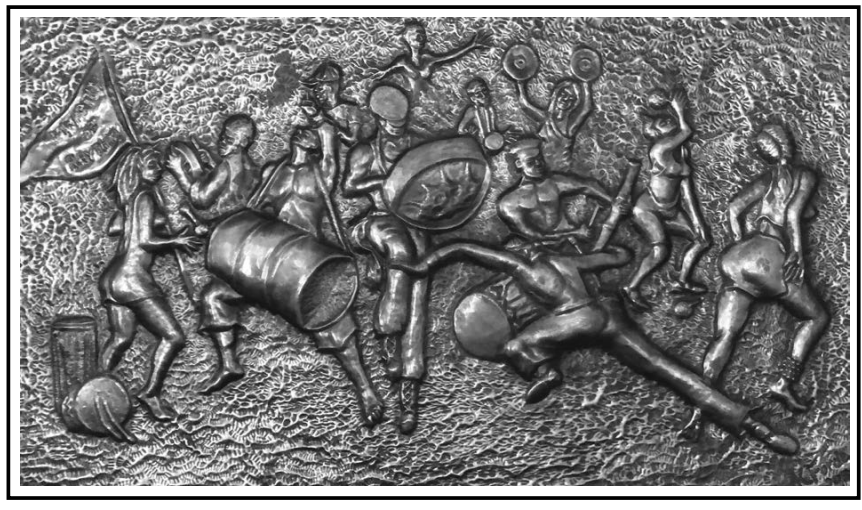

Adam Rudder is currently in his fourth year of undergraduate study at the University of Toronto pursuing a double major in Philosophy and Psychology with a minor in Caribbean Studies. He is a Canadian-Trinidadian student whose research interests include the intersections between Caribbean religions and political thought, and the role that ethnic and race relations play in the cultural hybridity of the Caribbean.

(C) 2021 Adam Rudder

Caribbean Studies Students'Union, Canada - https://jps.library.utoronto.ca/index.php/cquilt/

This work is licensed under the Creative Commons Attribution-ShareAlike 4.0 International License.

To view a copy of this license, visit https://creativecommons.org/licenses/by-sa/4.0/ 


\section{Introduction}

Throughout the Caribbean colonial era, extinction narratives were frequently used as a basis for dispossessing the region's Indigenous community of their land - a theme that persisted with the emergence of postcolonial states in the mid-20th century. One such example of this can be seen in Trinidad, where the politics, history, and nationalism of the country centred around the culture of its Afro-Creole population in an attempt to unify the character of the nation. Efforts for an Afro-Creole nationalism hindered the state's recognition of Indigenous concerns and ways of life however, and these efforts often grounded themselves upon narratives of Indigenous extinction. DNA and archaeological evidence have since shown that myths of Indigenous extinction are just that myths; the Indigenous community in Trinidad is greater than history would report. This paper argues that despite the diffusion of Trinidad's Indigenous community throughout the island, the post-independence government refrained from recognizing their concerns in an effort to preserve a nationalism that focused on the country's Afro-Creole population. It will attempt to argue this by analysing the extinction narratives that have served to confine Trinidad's Indigenous community. Next, the paper will investigate DNA evidence and historical writings that prove Indigenous diffusion beyond the limits outlined in extinction narratives. Finally, it will explore Trinidad's Afro-Creole-based nationalism to understand how it has inhibited the concerns of the overall Indigenous community.

\section{The Development of Extinction Narratives}

Myths about the extinction of Trinidad's Indigenous community stretch back to the British Empire's occupation of Trinidad at the end of the 18th century. Prior to their arrival, the island was shared between the Indigenous community and Spanish settlers. Maximilian Forte describes this Indigenous community as "a cosmopolitan mixture of people" who were "all assembled under the label of Carib," "a label that would help provide the foundation for later extinction narratives. Despite the Spanish's numerous failed attempts to inhabit the island, Trinidad's Indigenous population eventually eased their resistance to European colonization and came to tolerate Spanish presence on the island. ${ }^{2}$ The Indigenous community was not fully subjugated to colonial rule, and the Spanish typically adapted to the lifestyle carried out by their cohabitants. Over time, however, the power of Trinidad's Indigenous community waned as a result of the demographic decline of Indigenes throughout the Lesser Antilles. ${ }^{3}$ The Spanish gained more power and established missions across Trinidad, where the island's Indigenous community would ultimately be confined. When the British seized control of Trinidad from the Spanish in 1797, they brought with them an "administration of race" that would aid them in their classification of the island's inhabitants. ${ }^{4}$ Trinidad became a slave colony under the British Empire, and Indigenes would work as free labourers on British plantations for the first four decades of British rule. The British

\footnotetext{
${ }_{1}^{1}$ Maximilian Forte, "Carib Identity, Racial Politics and the Problem of Indigenous Recognition in Trinidad and Tobago," 174.

${ }^{2}$ Arie Boomert, The Indigenous Peoples of Trinidad and Tobago from the First Settlers Until Today, 97.

3 Boomert, 115.

${ }^{4}$ Forte, "Carib Identity, Racial Politics and the Problem of Indigenous Recognition in Trinidad and Tobago," 175.

5 Forte, 176.
} 
Empire expressed similar behaviours to their Spanish counterparts, in that they continued the practice of relocating and assigning Trinidad's Indigenous community to various missions throughout the island. By confining Indigenes to specific loci of land, it gave the colonial administration a means for classifying them geographically. Indigenous populations could now be calculated via inquiry of the missions' residents. Furthermore, the British practice of racialization and the creation of hierarchies based on race provided an avenue to marginalize the Indigenous groups on the island. Race became another technique for calculating the colony's Indigenous population, since racial mixture was viewed as a way to exempt someone of their indigeneity. The confinement of the Indigenous community to missions and the introduction of race allowed for the development of two useful extinction narratives for the colonial administration: extinction by miscegenation and extinction by localization.

Extinction by miscegenation was a narrative perpetuated by the British colonial administration in an attempt to hinder who could be recognized as Indigenous, and in turn, decrease the legitimacy of Indigenes claiming rights to land that the British sought to occupy. This extinction narrative is best captured in the words of Forte, who states that "the only real Carib is a pure Carib - and the only pure Carib is a dead Carib." ${ }^{\circ}$ The idea here is that the only people who could be recognized as Indigenous by the British were those of pure, Indigenous blood, and only they had any reasonable claims to the land. The colony of Trinidad was home to a number of different ethnic groups, including but not limited to people of African descent, European descent, Indigenous groups, and East Indians who would come to Trinidad in its post-emancipation era. Racial mixture mattered greatly to British authorities, as anyone who claimed Indigenous status lost the title if they were not of pure Indigenous ancestry? Under the British, the Indigenous community enjoyed certain rights not accessible to the African slave population and as such, the Indigenous community sat on a higher rung of the British hierarchy of race. ${ }^{8}$ Thus, racial mixture on the part of the Indigenes meant racial impurity for the colonial administration, and it would give them cause to divest Indigenous communities of their land and deny people access to their missions. This way, the population of Indigenous people residing on the missions would slowly but steadily decrease to a point where the British could claim Indigenous extinction, and moreover, justify their dispossession of Indigenous land. Localizing the Indigenous community to specific missions also served the purpose of proving Indigenous extinction. The later, post-independence government of Trinidad would use these localizations to inadvertently continue the dangerous narrative of Indigenous extinction.

The narrative of extinction was bolstered by the confinement of Indigenous people to missions across the colony of Trinidad, as this gave credence to the idea that a pure, Indigenous population had truly been wiped out and the only remaining ones were those on the missions.

\footnotetext{
${ }^{6}$ Forte, 180

${ }^{7}$ Forte, 178

8 Forte, 176.
} 
As mentioned previously, the Spanish were the first to establish missions in Trinidad, beginning in 1697 when the "Capuchin Missions" became the designated territory for all "free native populations in Central and South Trinidad." Though the British did not grant Indigenes this same title of freedom, they continued to use the missions as a means to constrain the Indigenous communities that were active on the island. This would have an injurious effect on the postcolonial society of Trinidad, as its government would continue the colonial practice of determining indigeneity based on residence within the missions. Throughout the 1970s, multiple administrations would come to recognize the presence of Indigenous people in the Trinidadian borough of Arima. ${ }^{10}$ The Santa Rosa First Peoples Community (SRFPC), formerly known as the Santa Rosa Carib Community, represents the Indigenous community present in Arima. The Trinidadian government recognized the SRFPC as a limited liability company in the latter half of the 20th century, designating the community as " "representative of the indigenous Amerindians of Trinidad and Tobago.",11 This designation is rather harmful, however, because by recognizing the SRFPC as a community that speaks for all Indigenous people on the island, the Trinidadian government bolsters the extinction narratives that have kept Indigenes unrecognized for so long. Indigenous concerns and practices are confined to the locus of Arima and the SRFPC, with no consideration given to the concerns of other overlooked Indigenous communities in
Trinidad. The SRFPC and Arima become the place of reference for outsiders seeking to understand indigeneity and its history in Trinidad. In turn, this extinguishes the history of the Indigenous folk located on other parts of the island, and the history of those who were banned from their Indigenous communities having been the product of miscegenation. Many extinction narratives in Trinidad have been preserved through continued miscegenation between Indigenous communities and other ethnic groups, and through the localization of Indigenous groups to specific parts of Trinidad. As a result, these narratives run counter to evidence of Indigenous dissemination, an area that will be explored in the following section.

\section{Indigenous Presence in Trinidad and Tobago}

The analysis of DNA evidence and historical documentation by scholars and researchers alike have produced evidence that Trinidad's Indigenous community is not only alive, but also extensive in the sociocultural makeup of the country. A recent study done on the biogeographical ancestries of Indigenous communities in Trinidad and Tobago found that patterns of genetic variation were consistent with the historical records of migration on the island prior to and after Spanish colonization. Benn Torres et al. confirm that there were more than eight different ethnic groups in the Caribbean at the instance of European arrival, ${ }^{12}$ bringing credence to the idea that the original inhabitants of Trinidad varied in ethnicity. As mentioned previously, the island's first inhabitants

\footnotetext{
${ }^{10}$ Forte, "Carib Identity, Racial Politics and the Problem of Indigenous Recognition in Trinidad and Tobago," 187.

${ }^{11}$ Forte, 187.

12Jada Benn Torres et al., "Analysis of Biogeographic Ancestry Reveals Complex Genetic Histories for Indigenous Communities of St. Vincent and Trinidad," 483.
} 
were a cosmopolitan mixture, which raises questions about the subsumption of this group under the singular label 'Carib.' It can be argued that this unilateral labelling was simply a means to advance extinction narratives, as it became easier for colonial administrations to determine indigeneity based on whether the subject at hand was 'Carib' or not. It also speaks volumes about the Trinidadian state's appointment of the SRFPC as the representative for all Indigenous peoples in the country. Recognizing the spokespeople for indigeneity as 'Carib' implies an ethnic group identification, and Benn Torres et al.'s research highlights why this identification cannot be made.

The participants of the study were all selected from the SRFPC, their genetic samples were collected, and genealogical interviews were conducted. The results of the study found high median amounts of Indigenous-American ancestry in the SRFPC sample, along with African, West Eurasian, and East and South Asian ancestries. ${ }^{13}$ The researchers note that the wide range of Indigenous ancestries found in the SRFPC sample was reflective of the gene flow of Indigenous groups from South America that moved between the coast of South America and Trinidad during the 19th century. ${ }^{14}$ These results are further proof that there is ethnic diversity in Trinidad's Indigenous population and that it is naive to classify the whole community as 'Carib.' Furthermore, the fact that African, West Eurasian, and East/South Asian ancestries were found in the SRFPC sample helps delegitimize claims of Indigenous extinction. If non-Indigenous DNA is found in a sample of self-identifying Indigenes, then it is plausible to suggest that Indigenous DNA would be found in the greater population of Trinidadians who do not claim Indigenous ancestry. The high median proportion of Indigenous DNA in the SRFPC sample was reflective of the marginalization that Indigenous communities faced at the hands of the British Empire. ${ }^{15}$ As such, it would come as no surprise if Indigenous ancestries were found in a random sample of the Trinidadian population, but further research must be done before one can make this claim unequivocally. Nevertheless, there are reasonable scientific grounds to suggest that the successors of Trinidad's first Indigenes had disseminated throughout the island. The colonial practice of ostracizing Indigenous communities to various missions on the island support this claim, as the rules attached to miscegenation allowed for the dispersal of "racially impure" Indigenous populations throughout the greater society of Trinidad.

Other examples of Indigenous continuity can be seen in historical documentation. In an article regarding the extinction myths perpetuated in the Caribbean, Forte makes mention of their incredulity. He highlights a major objection to extinction claims: Trinidad's Indigenous inhabitants never lost a decisive war, signed a treaty, or ceded their lands. ${ }^{1}$ Forte's assertion deauthorizes colonial claims of Indigenous extinction due to miscegenation, and postcolonial claims that Trinidad's Indigenous populations were wiped out during

\footnotetext{
${ }^{13}$ Benn Torres et al., 488.

${ }^{14}$ Benn Torres et al., 490.

${ }^{15}$ Benn Torres et al., 491.

${ }^{16}$ Maximilian Forte, "Extinction: Ideologies Against Indigeneity in the Caribbean," 48.
} 
colonization. Indigenous communities survived under the Spanish with the latter having to adopt Indigenous ways of living to subsist, while in the hands of the British, Indigenous communities were subject to the harsh realities of slavery, but still maintained their presence within the missions to which they were confined. ${ }^{17}$ Moreover, extinction by miscegenation fails to stand as a foundation for extinction ideologies, especially since miscegenation helps to expand Indigeneity rather than contain it. Admittedly, the colonial narrative around miscegenation was used to contain Indigeneity, but in practice, and as evidenced by DNA analysis, miscegenation serves as a method for expanding Indigeneity beyond an intra-ethnic scope. Further evidence of Indigenous dissemination can be seen in Spanish documentation of Indigenous communities at the time of their occupation. Throughout the 17th century, Spanish authorities confirmed that there were unknown numbers of Indigenous folk living in forested regions of Trinidad..$^{18}$ The practice of escape into the hinterlands was not uncommon to Indigenous groups throughout the Caribbean, as it was a way for them to survive the brutality of colonization. Having confirmed the existence of Indigenous populations in the forest regions of Trinidad, it becomes increasingly harder to defend narratives purporting Indigenous extinction. While there is little information documented about the lifestyles of these groups of people residing in the island's hinterlands, one can reasonably conclude that these communities eventually re-immersed themselves into Trinidadian society over the years ${ }^{9}{ }^{T}$ This further validates the aforementioned claim that Indigenous ancestries may be found in samples of Trinidad's current population, as Indigenes had a social reach that stretched beyond the confines of the colonial missions they were restricted to. Myths of Indigenous extinction lack any clear, valid evidence, and one may inquire into why such narratives were repeated in Trinidad post-independence.

\section{Afro-Creole Nationalism and Its Repercussions}

The post-independence government of Trinidad and Tobago was greatly concerned with nation-building and developing a national ethos, which had the negative effect of hindering Indigenous concerns. In personal communication with Tracy Assing, a member of the Indigenous community in Arima with close ties to the SRFPC, she discussed the fact that there were current initiatives being carried out by members of Trinidad's Indigenous community regarding state recognition of loss of land, culture, history, language, and way of life. ${ }^{20}$ The lack of state acknowledgement on these issues may very well be due to the government's initial efforts at nation-building after independence in 1962. Bridget Brereton cites the narrative that is typically produced by former colonies in the development of a new nation: it is usually based around heroic anticolonial struggles, it culminates into the achievement of a formal nationhood, and it ignores internal divisions. ${ }^{21}$ Brereton also points out that these narratives are generally ethnic in nature, and that they

\footnotetext{
${ }^{17}$ Steele, "Visibility and Meaningful Recognition for First Peoples: A Critical Discourse Studies Approach to Communication, Culture and Conflict Intersections in Seeking Social Justice," 494.

${ }^{18}$ Forte, "Extinction: Ideologies Against Indigeneity in the Caribbean," 55.

${ }^{19}$ Boomert, The Indigenous Peoples of Trinidad and Tobago from the First Settlers Until Today, 147.

${ }^{20}$ Tracy Assing, email message to author, December 2020.
} 
are employed in an effort to destabilize "linear nationalist histories" constructed by colonial powers.22 By producing an ethnic narrative of the former colonies' historiography, former colonies can counter any colonial documentation regarding their history. These narratives emerged in Trinidad post-independence and were heavily based on the experiences faced by the Afro-Creole population of the country. Much of this can be attributed to Eric Williams and his political party's rise to prominence, as his scholarly works provided the foundation of Trinidadian nationalism as it is today.

Eric Williams' History of the People of Trinidad and Tobago perpetuated an anticolonial, Afro-Creole narrative of Trinidad that would eventually permeate the nationalist discourse of the island. The book's central theme was the devastation brought by colonialism, and the Trinidadian people's struggle to overcome that history 3 While the book was unifying in that it acknowledged the subordination faced by all ethnic groups during colonialism in Trinidad, the book projected a view that Africans and their descendants represented the most important ethnic group in the nation. Eric Williams would go on to become the prime minister of Trinidad where his political party, the People's National Movement, would assume power for several years. Williams' book became the hegemonic narrative of Trinidad's past, and Afro-Creole arrangements had come to be regarded as the defining culture of the nation. ${ }^{24}$ To a degree, the Afro-Creole narrative was exclusive in that it pitted other ethnic groups as background characters in a rather multicultural nation. It also underplayed the contributions made by other ethnic groups to the development and history of the nation. The problem with the narrative is that it perpetuated an idea of Indigenous extinction that allowed the Trinidadian government to ignore calls for recognition of lost Indigenous culture. If one recalls Brereton's model, one can see the role that the Indigene plays in the nationalism of Trinidad and Tobago. Postcolonial representations of the Indigenous community posit them as the primordial heroes who first fought against colonization $^{25}$ the first tenet of Brereton's model includes anticolonial, heroic struggles as the basis for formal nationhood in former colonies. By nationalizing the Indigene as the hero, the government recognizes the Indigenous community's efforts in the fight against colonization, but it also serves as a model for how far Afro-Creole Trinidadians have come. ${ }^{26}$ This conceptualization of the Indigenous person is based on narratives of extinction, where the martyrdom of the Indigene serves the foundation for Afro-Creole progress. Essentially, the Indigenous community had to sacrifice their culture, land, language, and way of life to allow later Trinidadians to embrace modernity. Thus, the Indigene does not only serve as a national hero, but also the bridge that allowed modern Trinidadians to engage in nation-building and nationalist discourse. To grant the Indigenous community the recognition

\footnotetext{
${ }^{21}$ Bridget Brereton, "Contesting the Past: Narratives of Trinidad \& Tobago history," 170.

${ }^{22}$ Brereton, 171.

23 Brereton, 174.

24 Brereton, 176-177.

25 Maximilian Forte, Ruins of absence, presence of Caribs: (post)colonial representations of aboriginality in Trinidad and Tobago, 137-138.
} 
that they are asking for would be to deny a modern interpretation of Trinidad's historiography, a perceived backward step rather than one toward progress. The obsession over progress is a colonial attitude, perpetuated by the post-independence government of Trinidad, and Assing (2010) captures this attitude perfectly in stating the following: "houses take up spaces where [Indigenes] would have made [their] gardens." 27

\section{Conclusion}

This paper has argued that Trinidad's post-independence government's lack of recognition of Indigenous concerns was due to the country's ethnically-based nationalism founded on myths of Indigenous extinction. The essay has tried to prove this by outlining the relevant extinction narratives used to confine Indigenous populations on Trinidad, analysing DNA evidence and historical documentation as a means for disproving extinction narratives, and exploring the Afro-Creole nationalist rhetoric that has prevented government recognition of Indigenous concerns. Trinidad's formation as an independent state presented the country with an opportunity to move forward in spite of its colonial past. However, in making the move forward from a colonial history and developing an anticolonial future, a country must take account of the lived experiences of their entire demographic, for to neglect even one of these histories is to perpetuate colonial practices. Trinidad is one of the more progressive Caribbean nations in its recognition of its Indigenous population; however, more work needs to be done to address internal divisions. With further education of the Indigenous community's claims for lost land and culture, there remains hope that Trinidad will come together as one and be unified in any fight or push towards progress.

\footnotetext{
${ }^{26}$ Forte, 138-139.

27 Tracy Assing, The Amerindians.
} 


\section{Works Cited}

Assing, Tracy. The Amerindians. Directed by Sophie Meyer. 2010; Port of Spain: Trinidad and Tobago Film Company, 2010. DVD.

Benn Torres, Jada, Victoria Martucci, Melinda C. Aldrich, Miguel G. Vilar, Taryn MacKinney, Muhammad Tariq, Jill B. Gaieski, et al. "Analysis of Biogeographic Ancestry Reveals Complex Genetic Histories for Indigenous Communities of St. Vincent and Trinidad." American Journal of Physical Anthropology 169, no. 3 (May 2019): 482-497. https://doi-org.myaccess.library.utoronto.ca/10.1002/ajpa.23859.

Boomert, Arie. 2016. The Indigenous Peoples of Trinidad and Tobago from the First Settlers Until Today. Leiden: Sidestone Press.

Brereton, Bridget. "Contesting the Past: Narratives of Trinidad \& Tobago history." Nieuwe West-Indische Gids 81, no. 3-4 (2007): 169-196. https://www.jstor.org/stable/43390667.

Forte, Maximilian C. 2005. Ruins of absence, presence of Caribs: (post)colonial representations of aboriginality in Trinidad and Tobago. Gainesville: University Press of Florida.

Forte, Maximilian C. "Extinction: Ideologies Against Indigeneity in the Caribbean." The Southern Quarterly 43, no. 4 (2006): 46-69. http://myaccess.library.utoronto.ca/login?qurl=https $\% 3 \mathrm{~A} \% 2 \mathrm{~F} \% 2 \mathrm{Fwww}$.proquest. com\%2Fdocview\%2F222265546\%3Faccountid\%3D14771.

Forte, Maximilian C. 2013. "Carib Identity, Racial Politics and the Problem of Indigenous Recognition in Trinidad and Tobago." In Who is an Indian?: Race, Place and the Politics of Indigeneity in the Americas, 172-193. Toronto: University of Toronto Press.

Steele, Godfrey A. "Visibility and Meaningful Recognition for First Peoples: A Critical Discourse Studies Approach to Communication, Culture and Conflict Intersections in Seeking Social Justice.” Discourse \& Communication 14, no. 5 (May 2020): 489-511. https://doi.org/10.1177\%2F1750481320917553. 